\title{
Crossing Segregated
}

\section{Boundaries}




\title{
New Directions in the History of Education
}

\author{
Series editor, Benjamin Justice
}

The New Directions in the History of Education series seeks to publish innovative books that push the traditional boundaries of the history of education. Topics may include social movements in education; the history of cultural representations of schools and schooling; the role of public schools in the social production of space; and the perspectives and experiences of African Americans, Latinx Americans, women, queer folk, and others. The series will take a broad, inclusive look at American education in formal settings, from prekindergarten to higher education, as well as in out-of-school and informal settings. We also invite historical scholarship that informs and challenges popular conceptions of educational policy and policy making and that addresses questions of social justice, equality, democracy, and the formation of popular knowledge.

Diana D’Amico Pawlewicz, Blaming Teachers: Professionalization Policies and the Failure of Reform in American History

Dionne Danns, Crossing Segregated Boundaries: Remembering Chicago School Desegregation

Kyle P. Steele, Making a Mass Institution: Indianapolis and the American High School 


\section{Crossing Segregated Boundaries}

Remembering Chicago School Desegregation

DIONNE DANNS

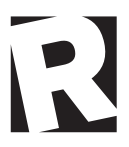

Rutgers University Press

New Brunswick, Camden, and Newark, New Jersey, and London 
Library of Congress Cataloging-in-Publication Data

Names: Danns, Dionne, author.

Title: Crossing segregated boundaries : remembering Chicago school desegregation / Dionne Danns.

Description: New Brunswick, New Jersey : Rutgers University Press, 2020.| Series: New directions in the history of education | Includes bibliographical references and index.

Identifiers: LCCN 2020004916 | ISBN 9781978810051 (paperback) | ISBN 9781978810068 (hardcover) | ISBN 9781978810075 (epub) | ISBN 9781978810082 (mobi) | ISBN 9781978810099 (pdf)

Subjects: LCSH: School integration-Illinois-Chicago-History. Public schools-Illinois-Chicago-History. | African American children-Education-Illinois-Chicago-History. | High school graduates-Illinois-Chicago. | Chicago (Ill.) - Race relations. |

Chicago (Ill.)-Ethnic relations.

Classification: LCC LC214.23.C54 D359 2020 | DDC 379.2/630977311-dc23

LC record available at https://lccn.loc.gov/2020004916

A British Cataloging-in-Publication record for this book is available from the British Library.

Maps created by Jordan Blekking

Copyright $\odot 2021$ by Dionne Danns

All rights reserved

No part of this book may be reproduced or utilized in any form or by any means, electronic or mechanical, or by any information storage and retrieval system, without written permission from the publisher. Please contact Rutgers University Press, 106 Somerset Street, New Brunswick, NJ 0890 . The only exception to this prohibition is "fair use" as defined by U.S. copyright law.

$\ominus$ The paper used in this publication meets the requirements of the American National Standard for Information Sciences-Permanence of Paper for Printed Library Materials, ANSI Z 39.48-1992.

www.rutgersuniversitypress.org

Manufactured in the United States of America 
For my grandmothers, Deborah and Molly And those who shared their stories 
